ISSN : 2550-0198

\title{
OPTIMALISASI POTENSI PELAYANAN PENDIDIKAN MELALUI PEMANFAATAN TEKNOLOGI INFORMASI PADA PENERAPAN SISTEM INFORMASI UJIAN BERBASIS KOMPUTER DISMK KEUANGAN PEKANBARU
}

\author{
Mitra Unik, Evans Fuad, Baidarus, Harun Mukhtar, Hasanuddin, Januar Al \\ Amien \\ Teknik Informatika, Fakultas Ilmu Komputer \\ *Email:mitraunik@umri.ac.id
}

\begin{abstract}
Abstrak
Pemikiran pemanfaatan teknologi Informasi yang identik dengan biaya mahal, membuat beberapa pihak instansi pendidikan/sekolah merasa enggan untuk menerapkannya, padahal dengan demikian dapat memberikan keuntungan dalam efisien waktu, tenaga dan penyajian informasi. Penghematan waktu dan kecepatan penyajian informasi akibat penerapan teknologi informasi tersebut akan memberikan kesempatan kepada pihak guru dan pimpinan sekolah untuk meningkatkan kualitas informasi dan pembinaan kepada siswa. Aktifitas tes/ujian tidak hanya dilakukan sebagai mekanisme kenaikan kelas maupun kelulusan namun kini juga sebagai mekanisme ujian masuk sekolah tersebut. Ujian berbasis komputer (UBK) dianggap juga sebagai implementasi pengetahuan dari pembelajaran TIK, karena dengan UBK ampu menempatkan siswa sebagai pelaku teknologi yang bermanfaat, dimana mereka dihadapkan pada kemampuan untuk mengoperasikan perangkat komputer. Tindakan dalam kegiatan ini berupa implementasi Program. Kegiatan-kegiatan yang dilakukan dalam implementasi program adalah sebagai berikut. Melakukan inplementasi sistem pada komputer yang diperuntukkan sebagai server. Melakukan pelatihan penggunaan software/sistem yang diberikan.
\end{abstract}

Kata kunci: UBK, Tenologi Informasi, Siswa, Sekolah

\section{PENDAHULUAN}

Pengembangan layanan pendidikan merupakan hal yang mesti diprioritaskan untuk kelangsungan pendidikan, sehingga menghasilkan impact yang diinginkan. Hadirnya Teknologi Informasi (IT) yang berkembang semakin kompleks mendorong pemanfaatan teknologi informasi bagi instansi pendidikan. Pada tingkat pendidikan sekolah menengah atas khususnya di kabupaten meranti, implikasi IT baru sebatas penyesuaian kurikulum atau penambahan mata kuliah tambahan yang diajarkan untuk siswa dan belum mencakup pada ranah pemanfaatan sebagai penunjang proses belajar mengajar secara menyeluruh seperti guna aktifitas UJIAN. Sedangkan di sisi intitusipemanfaatan Teknologi Informasi pada umumnya baru mencakup ranah penggunaan WEBSITE sebagai media promosi/profile sekolahdan layanan E-mail sebagai media komunikasi surat elektronik.

Pemikiran pemanfaatan teknologi Informasi yang identik dengan biaya mahal, membuat beberapa pihak instansi pendidikan/sekolah merasa enggan untuk menerapkannya, 
ISSN : 2550-0198

padahal dengan demikian dapat memberikan keuntungan dalam efisien waktu, tenaga dan penyajian informasi. Penghematan waktu dan kecepatan penyajian informasi akibat penerapan teknologi informasi tersebut akan memberikan kesempatan kepada pihak guru dan pimpinan sekolah untuk meningkatkan kualitas informasi dan pembinaan kepada siswa. Aktifitas tes/ujian tidak hanya dilakukan sebagai mekanisme kenaikan kelas maupun kelulusan namun kini juga sebagai mekanisme ujian masuk sekolah tersebut.

Ujian berbasis komputer (UBK) dianggap juga sebagai implementasi pengetahuan dari pembelajaran TIK, karena dengan UBK ampu menempatkan siswa sebagai pelaku teknologi yang bermanfaat, dimana mereka dihadapkan pada kemampuan untuk mengoperasikan perangkat komputer.

Memperhatikan kondisi sekolah yang jauh dari jangkauan pusat kota dan kurangnya kegiatan pelatihan yang diikuti oleh guru khusunya dalam pemanfaatan IT dalam proses pembelajaran, maka dipandang perlu untuk melaksanakan kegiatan pengabdian dengan melibatkan guru. Kegiatan ini akan dilaksanakan di salah satu sekolah di Kecamatan Marpoyan Damai, Kota Pekanbaru, dengan melibatkan semua guru

\section{PERMASALAHAN MITRA PENGABDIAN}

Diterapkan aturan oleh Dinas Pendidikan Provinsi Riau bahwa setiap sekolah jenjang menengah atas mesti memiliki LAB komputer yang memiliki fasilitas UBK (Ujian
Berbasis Komputer) membuat permasalahan baru bagi pihak sekolah. Oleh sebab itu pihak sekolah sangat memerlukan Sistem Informasi Ujian Berbasis Komputer (SIUBEK).

Memperhatikan kondisi sekolah yang jauh dari jangkauan pusat kota dan kurangnya kegiatan pelatihan yang diikuti oleh guru khusunya dalam pemanfaatan IT dalam proses pembelajaran, maka dipandang perlu untuk melaksanakan kegiatan pengabdian dengan melibatkan guru. Kegiatan ini akan dilaksanakan di salah satu sekolah di Kecamatan Marpoyan Damai, Kota Pekanbaru, dengan melibatkan semua guru.

\section{METODE PELAKSANAAN}

Pelaksanaan kegiatan pengabdian kepada masyarakat di SMK Keuangan Pekanbaru dimaksud kan untuk membantumengatasi persoalan serta mengoptimalisasi potensi pelayanan pendidikan. Tahapan kegiatan yang dijalankan meliputi persiapan, pelaksanaan pengabdian dan evaluasi.

\section{Tahap Persiapan,}

Melakukan koordinator teknis di lapangan dengan pihak SMK Keuangan Pekanbaru untuk mempersiapkan kegiatan yang akan dilaksanakan.

Tim pengabdi melakukan obsevasi pendahuluan untuk mengetahui kondisi di lapangan mengenai optimalisasi potensi layanan pendidikan SMK Keuangan Pekanbaru. Dalam tahap ini dicari permasalahan-permasalahan yang dihadapi oleh Pihak sekolah dalam 


\section{ISSN : 2550-0198}

mengoptimalisasi potensi layanan pendidikan

Pelatihan dilaksanakan di tempat/ruangan yang memadai untuk penyelenggaraan pelatihan.

Materi pelatihan disusun oleh Tim Pelaksana Pengabdian Kepada Masyarakat Prodi Teknik Informatika, FASILKOM, UMRI yang terdiri dari staf pengajar di Prodi Teknik Informatika.

Materi pelatihan disajikan dalam bentuk persentasi dan diperbanyak sesuai dengan jumlah peserta pelatihan dalam bentuk print-out.

Selain materi dalam bentuk printout, untuk keperluan peragaan, demonstrasi dan praktik, Tim pelaksana juga menyediakan alat-alat dan bahan-bahan yang diperlukan untuk kegiatan pelatihan tersebut.

Tahap Pelaksanaan Pengabdian, tahap ini pengabdi melakukan kegiatan Penerapan Sistem Informasi Ujian Berbasis Komputer serta Pengarahan dan pelatihan (Workshop) dalam mengelola sistem secara mandiri.

Tahap Evaluasi, Evaluasi diberikan dengan cara melakukan uji langsung pada operator yang ditunjuk pihak sekolah dalam mengelola sistem secara benar

\section{HASIL DAN PEMBAHASAN}

Hasil yang dicapai melalui kegiatan pengabdian ini dituangkan dalam bentuk hasil kegiatan pada setiap tahap pelaksanaan sebagai berikut :

\section{Perencanaan}

Kegiatan-kegiatan yang dilakukan pada tahap perencanaan adalah sebagai berikut.

Pemberitahuan pada sekolah mitra yang akan dijadikan lokasi pengabdian terkait. Pelaksanaan tahap ini didahului dengan mengirim surat pemberitahuan kepada pihak sekolah. Setelah itu dilakukan koordinasi untuk membahas teknis pelaksanaan kegiatan. Kegiatan ini dilaksanakan pada minggu ke-2 bulan Agustus tahun 2017.

Sosialisasi program pengabdian Sosialisasi dilakukan pada minggu ke-4 bulan Juli 2017 dengan melakukan koordinasi dan menyampaikan pemberitahuan secara tertulis kepada kepala sekolah SMK Keuangan Pekanbaru.

Penyusunan program pelatihan Berdasarkan hasil identifikasi, hasil analisis permasalahan yang ada, hasil analisis kebutuhan, dan hasil analisis potensi sekolah, selanjutnya disusun program pelatihan. Pelaksanaan pelatihan dilakukan selama 1 hari tatap muka, dengan mengundang para guru-guru tersebut. Pelatihan yang diberikan berupa implementasi Sistem Informasi Ujian Online di SMK Keuangan Pekanbaru

\section{Pelaksanaan Tindakan}

Tindakan dalam kegiatan ini berupa implementasi Program. Kegiatan-kegiatan yang dilakukan dalam implementasi program adalah sebagai berikut.

Melakukan inplementasi sistem pada komputer yang diperuntukkan sebagai server. 
ISSN : 2550-0198

Melakukan pelatihan penggunaan software / sistem yang diberikan.

1. Pembahasan

Kegiatan pengabdian yang dilaksanakan pada guru-guru SMK Keuangan Pekanbaru telah berlangsung dengan baik. Hal ini terlihat dari animo guru untuk mengikuti kegiatan pelatihan sangat tinggi. Hal ini mengindikasikan bahwa para guru menyambut positif kegiatan yang telah dilakukan. Sesuai dengan harapan para sekolah, mereka sangat mengharapkan adanya kegitan-kegiatan yang sifatnya memberi penyegaran bagi para guru di daerah ini, baik terkait dengan pendalaman materi bidang studi ataupun terkait dengan metode mengajar dan media pembelajaran. Kepala sekolah dan guru-guru menyambut antusias terkait pelaksanaan kegiatan inidan berharap pelaksanaan kegiatan dapat dilakukan secara berkelanjutan untuk membantu meningkatkan kualitas guru-guru yang mengabdi di daerah.

\section{SIMPULAN}

Hasil yang dicapai melalui kegiatan ini adalah sebagai berikut.

a. Terimplementasi sistem ujian online / ujian berbasis komputer di SMK Keuangan Pekanbaru.

b. Peningkatan mutu dan pengetahuan peserta terkait teknologi informasi khusus nya sistem ujian berbasis komputer

$\begin{array}{llr}\begin{array}{l}\text { Beberapa } \\ \text { saran yang }\end{array} & \text { dapat } \\ \text { disampaikan } & \text { berdasarkan } & \text { hasil } \\ \text { pelaksanaan kegiatanini } & \text { adalah } \\ \text { sebagai berikut: }\end{array}$

a. Sekolah diharapkan dapat menambah fasilitas komputer dan perangkat jaringan komputernya

b. Adanya admin/operator IT yang mampu menguasai sistem dengan baik, sehingga dapat mengembangkan sistem secara mandiri.

\section{UCAPAN TERIMAKASIH}

Alhamdulillahirobbilalamin, segala puji bagi Allah SWT Tuhan semesta alam, semoga shalawat dan salam selalu tercurah pada junjungan kita Nabi Besar rasullullah SAW, para keluarga dan sahabat.

Terimakasih kami sampaikan kepada semua pihak terutama LPPM Universitas Muhammadiyah Riau yang telah mendanai pengabdian kepada masyarakat pada tahun 20162017, Kepala sekolah dan guru SMK Keuangan Pekanbaru, semoga kegiatan ini dapat memberikan manfaat bagi pihak sekolah.

\section{DAFTAR PUSTAKA}

[1] Hanif al fatta, 2007, Analisis dan perancangan sistem informasi untuk

[2] keunggulan bersaing perusahaan dan organisasi modern, CV Andi offset, yogyakarta.

[3] Irmansyah, F, 2003, Pengantar Database. Jakarta : Ilmu Komputer

[4] Kusworo.A.P. 2010. Pembuatan Sistem Ujian Online. Penelitian. Program Studi Ilmu Komputer Fakultas Matematika dan Ilmu Pengetahuan Alam Universitas Sebelas Maret. Surakarta 


\section{ISSN : 2550-0198}

[5] Kusrini dan andri koniyo,2007, tuntutan praktis membangun sistem informasi akuntansi dengan visual basic dam Microsoft SQL server, Andi offset, yogyakarta

[6] Peranginangin, K.2006. Aplikasi WEB dengan PHP dan MySQL. Yogyakarta. Andi

[7] Sasria.H.2007. Aplikasi PHP dan MySQL Dalam Pembuatan Sistem Informasi SMAN1 Dukuhwaru Kabupaten Tegal Berbasis Web. Penelitian. Program Studi Statistika Terapan dan Komputasi fakultas matematika dan ilmu pengetahuan alam Universitas negeri. Semarang 